\title{
PENGARUH PERMAINAN TREASURE HUNT TERHADAP KECERDASAN INTERPERSONAL ANAK USIA 5-6 TAHUN
}

\author{
Pia Permata Putri ${ }^{1}$, Sumardi $^{2}$, Sima Mulyadi $^{3}$ \\ ${ }^{1}$ Program Studi PGPAUD UPI Kampus Tasikmalaya \\ ${ }^{2}$ Program Studi PGPAUD UPI Kampus Tasikmalaya \\ ${ }^{3}$ Program Studi PGPAUD UPI Kampus Tasikmalaya \\ Email: piapermataputri@gmail.com
}

(Received: Mei 2020; Accepted: Mei 2020; Published: Juni 2020)

\begin{abstract}
This research is motivated by problems encountered in the Kindergarten Institute related to learning activities that are still academic in nature. Ideally the implementation of learning in schools can stimulate and optimize all multiple intelligences in early childhood. But the reality on the ground there are problems in the development of interpersonal intelligence because learning is still academic and the lack of specific variations such as game media in learning activities to improve children's interpersonal intelligence abilities. One of the media to stimulate the development of children's interpersonal intelligence is by using the game treasure hunt. This is the background of the study. The research aims to determine the effect of games treasure hunt on interpersonal intelligence of children aged 5-6 years. The research method used is the study of literature. The types and sources of data used by researchers are using secondary data and sources. Data collection techniques carried out are from some of the results of previous books and journal data relevant to the topic of the problem raised by the researcher. Based on the results of data from several findings that have been made by previous researchers, it can be concluded that by applying the game treasure hunt can affect the interpersonal intelligence of children aged 5-6 years.
\end{abstract}

Keywords: treasure hunt games; interpersonal intelligence; early childhood.

\begin{abstract}
ABSTRAK
Penelitian ini dilatarbelakangi oleh permasalahan yang ditemui di Lembaga Taman Kanak-kanak berkaitan dengan kegiatan pembelajaran yang masih bersifat akademis. Idealnya pelaksanaan pembelajaran di sekolah dapat menstimulus dan mengoptimalkan seluruh kecerdasan jamak pada anak usia dini. Namun kenyataan di lapangan terdapat permasalahan dalam perkembangan kecerdasan interpersonal karena pembelajaran masih bersifat akademis dan kurangnya variasi khusus seperti media permainan dalam kegiatan pembelajaran untuk meningkatkan kemampuan kecerdasan interpersonal anak. Media untuk menstimulus perkembangan kecerdasan interpersonal anak salah satunya dengan menggunakan permainan treasure hunt. Hal tersebut menjadi latar belakang dilaksanakannya penelitian. Adapun penelitian ini bertujuan untuk mengetahui pengaruh permainan treasure hunt terhadap kecerdasan interpersonal anak usia 5-6 tahun. Metode penelitian yang digunakan adalah studi literatur. Jenis dan sumber data yang digunakan oleh peneliti yaitu dengan menggunakan data dan sumber sekunder. Teknik pengumpulan data yang dilakukan yaitu dari beberapa hasil data buku dan jurnal terdahulu yang relevan sesuai dengan topik permasalahan yang diangkat oleh peneliti. Berdasarkan hasil data dari beberapa temuan yang telah dilakukan oleh peneliti terdahulu, maka dapat disimpulkan bahwa dengan menerapkan permainan treasure hunt dapat berpengaruh terhadap kecerdasan interpersonal anak usia 5-6 tahun.
\end{abstract}

Kata Kunci: Permainan Treasure Hunt;Kecerdasan Interpersona; Anak Usia Dini 


\section{PENDAHULUAN}

Pendidikan adalah hal yang paling mendasar dan penting bagi kehidupan, khususnya Pendidikan pada anak usia dini. Dimana Pendidikan anak usia dini merupakan Pendidikan awal dan utama dalam kelangsungan hidupnya. Dengan adanya Pendidikan dapat terwujudnya pengetahuan, sikap dan keterampilan yang dibutuhkan dalam kehidupan sesuai dengan apa yang diperlukan. UndangUndang Sistem Pendidikan Nasional No. 20 Tahun 2003 menyebutkan bahwa "Pendidikan anak usia dini merupakan anak usia sejak lahir sampai dengan usia enam tahun yang dilakukan melalui pemberian rangsangan Pendidikan untuk membantu pertumbuhan dan perkembangan jasmani maupun rohani agar anak memiliki kesiapan dalam memasuki Pendidikan lebih lanjut". Pendidikan adalah hal utama yang paling mendasar. Hal tersebut hendaknya didukung oleh sarana dan prasarana yang memadai agar proses pembelajaran berjalan dengan optimal. Tidak hanya fasilitasnya saja yang harus diperbaharui, melainkan seorang pendidiknya pun harus memiliki kecerdasan dalam mengembangkan proses pembelajaran yang dapat memotivasi, kondusif serta menyenangkan bagi anak didik.

Mengacu pada Permendikbud RI No. 137 Tahun 2014 Pasal 10 tertulis bahwa "Lingkup perkembangan anak mencakup aspek agama dan moral, fisik motorik, kognitif, bahasa, sosial emosional dan seni." Perkembangan sosial merupakan salah satu aspek dalam ruang lingkup perkembangan anak usia dini. Kecerdasan interpersonal ini sangatlah diperlukan bagi kehidupan anak dalam bersosial. Anak yang memiliki keterampilan sosial yang baik akan lebih membantu dan efektif dalam menjalankan hubungan sosial dengan lingkungannya. Dalam Permendikbud No. 146 Tahun 2014 terdapat indikator pencapaian perkembangan anak usia 5-6 tahun dalam aspek sosial diantaranya : anak dapat berperilaku sopan dan peduli baik melalui perkataan dan perbuatannya secara spontan (seperti mampu mengucapkan maaf, permisi, terima kasih); anak menunjukan sikap mau menolong baik itu kepada orang tua, pendidik serta teman sebayanya; anak dapat memecahkan sendiri masalah sederhana yang dihadapinya; anak dapat beradaptasi secara wajar dalam situasi yang baru.

Kecerdasan interpersonal merupakan kemampuan untuk berhubungan dengan orang-orang di sekitar. Hal ini sejalan dengan May Lwin dkk. (2008, hlm. 197) mengungkapkan bahwa "Kecerdasan interpersonal adalah kemampuan untuk berhubungan dengan orang-orang di sekitar kita. Kecerdasan ini adalah kemampuan untuk memahami dan memperkirakan perasaan, temperamen, suasana hati, maksud dan keinginan orang lain dan menanggapinya secara layak". Oleh karena itu, kecerdasan interpersonal dapat didefinisikan sebagai kemampuan mempersepsikan dan membedakan suasana hati, pikiran, keinginan serta kemampuan memberikan respon secara tepat terhadap orang lain. Dengan memiliki kecerdasan interpersonal, anak dapat merasakan apa yang dirasakan orang lain, menangkap maksud dari orang lain dengan bertindak sesuatu, serta mampu.dalam menjalin hubungan antar pribadi. Maka dari itu kecerdasan interpersonal bagi anak usia dini memiliki manfaat yang besar bagi dirinya sendiri dan bagi perkembangan sosialnya. Anak perlu dibiasakan untuk bersosialisasi dengan lingkungannya, seperti pengendalian diri, komunikasi, simpati, empati, berbagi, serta dalam hal bekerjasama dengan orang lain.

$$
\text { Kenyataan yang terjadi di }
$$

kelompok B pada TK Artanita AlKhoeriyah bahwa masih terdapat permasalahan dalam perkembangan kecerdasan interpersonal anak karena pembelajaran masih bersifat akademis, metode pembelajaran pun kurang menarik sehingga masih ada anak yang diam tidak 
mau mengikuti pembelajaran, bermain secara sendiri-sendiri, bermain dengan kelompok tertentu saja, anak tidak dapat bekerja sama dengan teman yang lain atau pemilih yang mengakibatkan tidak adanya interaksi ataupun kerjasama antara anak satu dengan anak lain secara keseluruhan. Hal ini berdasarkan wawancara dengan guru kelas B di TK Artanita Al-Khoeriyah bahwa permasalah yang dihadapi yaitu dalam perkembangan kecerdasan interpersonal pada anak usia 5-6 tahun.

Adapun penelitian yang dilakukan oleh Sumantri M. S, Sugito, (2015) yang berjudul "Implementasi Metode Bermain Peran untuk Meningkatkan Kecerdasan Interpersonal Anak Usia 5-6 Tahun di TK Barunawati”. Hasil penelitian ini menunjukan bahwa dengan mengimplementasikan metode bermain peran kecerdasan interpersonal anak meningkat. Adapun besar peningkatannya adalah $76 \%$. Hal ini menunjukan bahwa terdapat peningkatan yang sangat baik.

Berdasarkan latar belakang tersebut maka rumusan masalah yang akan dibahas adalah permasalahan dalam perkembangan kecerdasan interpersonal anak usia 5-6 tahun dan kemampuan kecerdasan interpersonal setelah menggunakan permainan treasure hunt.

Tujuan dari penelitian ini adalah untuk mendeskripsikan permasalahan dalam perkembangan kecerdasan interpersonal anak usia 5-6 tahun dan kemampuan kecerdasan interpersonal setelah menggunakan permainan treasure hunt.

Sejalan dengan paparan diatas, pembelajaran dengan menggunakan permainan dipandang relevan jika diterapkan untuk meningkatkan kecerdasan interpersonal anak. Oleh karena itu, fokus penelitian ini adalah untuk mengetahui adakah pengaruh positif yang signifikan dari permainan treasure hunt terhadap kecerdasan interpersonal anak usia 5-6.

\section{TINJAUAN PUSTAKA}

2.1 Pengertian Pendidikan Anak Usia Dini

Dalam Undang-Undang Sistem Pendidikan Nasional No. 20 Tahun 2003 menyebutkan bahwa "Pendidikan anak usia dini merupakan anak usia sejak lahir sampai dengan usia enam tahun yang dilakukan melalui pemberian rangsangan pendidikan untuk membantu pertumbuhan dan perkembangan jasmani maupun rohani agar anak memiliki kesiapan dalam memasuki Pendidikan lebih lanjut".

Selain itu Sujiono (2009, hlm 8) menyatakan bahwa "Pendidikan anak usia dini merupakan bagian dari pencapaian tujuan pendidikan nasional yaitu dalam mencerdaskan kehidupan bangsa dan mengembangakn manusia Indonesia yang seutuhnya".

Pada Permendikbud RI No. 137 Tahun 2014 Pasal 10 tertulis bahwa "Lingkup perkembangan anak meliputi aspek agama dan moral, fisik motorik, kognitif, bahasa, sosial emosional dan seni." Perkembangan sosial merupakan salah satu aspek dalam ruang lingkup perkembangan anak usia dini. Kecerdasan interpersonal anak sangatlah diperlukan bagi kehidupan bersosial. Anak yang memiliki keterampilan sosial yang baik akan lebih efektif dalam menjalankan hubungan sosial dengan lingkungannya.

Berdasarkan pernyataan diatas dapat disimpulkan bahwa anak usia dini adalah anak yang memiliki kemampuan untuk belajar yang sangat luar biasa khususnya pada masa golden age. Usia keemasan ini hanya datang satu kali dan tidak dapat terulang kembali. Maka dari itu kesempatan ini hendaknya dapat dimanfaatkan oleh lingkungan di sekelilingnya, seperti keluarga, sekolah dan masyarakat sekitar untuk membantu dan memberikan berbagai stimulus kepada anak serta mengembangkan potensinya sebagai upaya pengoptimalan pertumbuhan dan perkembangan yang dimiliki anak. 
Bellanca (2011 hlm. 196) menyatakan permainan "Treasure hunt merupakan suatu metode yang bertujuan untuk menemukan objek-objek yang mewakili konsep-konsep dalam pembelajaran. Kecerdasan yang terlibat dalam penerapan permainan treasure hunt adalah verbal (linguistik), visual (spasial), dan interpersonal". Jadi metode ini dapat digunakan untuk mengembangkan kecerdasan interpersonal anak.

Kohen, dkk. (2012 hlm. 24) mengungkapkan bahwa "Treasure hunt merupakan salah satu pendekatan yang menggabungkan aktivitas dalam dan luar ruangan. Dalam permainan ini, siswa ditantang untuk mengidentifikasi petunjuk atau clue untuk mencapai harta karun". Berbagai kegiatan dapat ditambahkan untuk membuat permainan treasure hunt agar lebih berkesan. Permainan ini dapat dimainkan secara tim atau berkelompok.

Permainan ini dapat

meningkatkan aktivitas belajar siswa karena pada dasarnya anak usia dini sangat aktif dan suka bermain. Melalui bermain, dapat memperoleh pembelajaran serta dapat meningkatnya sikap kerjasama, bersikap sportif, saling menghargai.

2.2.1 Manfaat Permainan Treasure Hunt

Adapun menurut Rofiah (2017, hlm. 23) metode permainan treasure hunt memiliki 3 manfaat sebagai berikut :

1) Menumbuhkan sikap kerjasama, karena setiap siswa berkontribusi dalam melakukan permainan.

2) Menimbulkan antusias untuk memecahkan setiap clue, karena setelah memecahkan clue kelompok akan mendapat harta karun

3) Menumbuhkan semangat siswa dalam memecahkan setiap clue.

2.2.2 Langkah-langkah Permainan Treasure Hunt

Menurut Kim dan Yao (2010 hlm. 1858) ada empat fase dalam menerapkan metode permainan treasure hunt, yaitu: 1)
Fase Penyajian; 2) Fase Mengingat; 3)

Fase Pengembangan; 4) Fase Evaluasi.

2.3 Kecerdasan Interpersonal

Howard Gardner (2003, hlm. 23)

mengatakan kecerdasan merupakan kemampuan memecahkan masalah yang dinilai oleh satu atau lebih setting budaya. Dia mengatakan bahwa :

Kecerdasan adalah kemampuan memecahkan masalah, atau menciptakan produk-produk yang dinilai oleh satu setting budaya atau lebih. Kecerdasan terbagi menjadi 8 jenis, diantaranya : kecerdasan verbal/linguistik; kecerdasan logismatematis; kecerdasan visual /spasial; kecerdasan musikal; kecerdasan kinestetik; kecerdasan interpersonal; kecerdasan intrapersonal; kecerdasan spiritual. Dalam hal ini semua aspek perlu dikembangkan karena masa ini sangat berperan di semua aspek, salah satunya aspek sosial dan aspek sosial dapat dikembangkan melalui aspek kecerdasan interpersonal. (hlm. 97)

Lwin, dkk. (2008 hlm. 197) mengungkapkan bahwa "Kecerdasan Interpersonal adalah kemampuan untuk berhubungan dengan orang-orang di sekitar kita. Kecerdasan ini adalah kemampuan untuk memahami dan memperkirakan perasaan, temperamen, suasana hati, maksud dan keinginan orang lain dan menanggapinya secara layak".

Jinshon (dalam Fitriani, 2016, hlm. 7) menyatakan bahwa keterampilan interpersonal merupakan dasar seseorang untuk memulai suatu hubungan sosial yang tepat, yaitu bagaimana memahami reaksi seseorang dan memberikan respon yang tepat. Oleh karena itu keterampilan interpersonal sangatlah penting bagi anak usia dini, menjadi penting karena pada dasarnya manusia adalah makhluk sosial dimana manusia tidak bisa hidup sendiri. Selanjutnya Mork (dalam Yaumi, 2013, hlm. 131) mengungkapkan bahwa kecerdasan interpersonal menekankan pada empat elemen penting yang perlu 
digunakan dalam berkomunikasi, diantaranya: (1) membaca isyarat sosial, (2) memberikan empati, (3) mengontrol emosi, dan (4) mengekspresikan emosi pada tempatnya.

Dari berbagai pendapat dapat disimpulkan bahwa kecerdasan interpersonal merupakan kemampuan seseorang dalam berhubungan sosial atau berinteraksi dalam memahami pikiran, sikap, perilaku orang lain, bekerja sama, serta dalam berinteraksi maupun berhubungan sosial anak mampu menggali/menerima suatu informasi, merespon dan membangun hubungan yang baik ataupun harmonis dengan orang lain.

2.3.1 Dimensi Kecerdasan Interpersonal

Anderson (dalam Safaria, 2005 hlm. 24) menjelaskan bahwa kecerdasan interpersonal memiliki 3 dimensi, diantaranya:

1) Sensitivitas Sosial

Kemampuan seseorang dalam mengamati dan merasakan berbagai macam simbol ataupun reaksi pada individu yang kemudian direspon dengan baik dalam bentuk verbal maupun non verbal. Anak yang memiliki sensitivitas sosial yang tinggi akan mudah memahami dan menyadari simbol atau reaksi tertentu dari orang lain seperti sikap empati dan sikap prososial. Sikap empati sangat dibutuhkan dalam proses bersosialisasi. Sedangkan sikap prososial merupakan sikap berbagi, kerjasama, membantu orang lain, dan menunjukan sikap simpati.

2) Pemahaman Sosial

Kemampuan dalam memahami serta memecahkan masalah di dalam interaksi sosial. Sehingga permasalahan yang ada tidak akan menghambat hubungan sosial yang sudah terbentuk sebelumnya. Pondasi dalam pemahaman sosial adalah berkembangnya kesadaran individu untuk membangun hubungan dalam bermusyawarah dengan baik. Kesadaran diri inilah yang akan membuat seseorang mampu untuk memahami dirinya sendiri, baik itu internal maupun eksternal. Seperti menyadari emosinya yang sedang muncul dan terampil dalam memecahkan masalah, dan paham akan situasi sosial. Dalam menyadari emosinya tersebut anak dapat membangun hubungan yang harmonis kepada orang lain berdasarkan kesadaran terhadap dirinya sendiri, misalnya anak mau mengucapkan dan menjawab salam; anak mau bercerita apa yang dialaminya kepada orang lain; dan dalam bermain dengan orang lain anak mampu memimpin diskusi serta merumuskan peraturan-peraturan penyelesaian tugas bersama temannya.

3) Komunikasi Sosial

Kemampuan seseorang dalam merespon entah dalam bentuk verbal maupun non verbal dengan baik. Kemampuan merespon ini mencakup kecakapan anak dalam berkomunikasi seperti, dalam keterampilan berbicara, menulis, publik speaking, sampai mendengarkan dengan efektif, membaca simbol dan lain sebagainya. Dalam komunikasi sosial dicontohkan seperti anak mampu merespon informasi maupun menggali informasi seperti menjawab, menyapa, dan bertanya kepada orang lain.

2.3.2 Karakteristik Kecerdasan Interpersonal

Beberapa karakteristik kecerdasan interpersonal yang dikemukakan Suparno (2013, hlm. 47-48) diantaranya:

1) Mudah bekerjasama dengan orang lain

2) Mudah mengenal dan membedakan perasaan pribadi dan orang lain

3) Kemampuan menggali/menerima informasi

4) Mampu merespon

5) Mengorganisasi teman-temannya untuk melakukan tugas

6) Memiliki banyak teman dan mampu menjalin hubungan dengan temantemannya

7) Sering menjadi pemimpin diantara temantemannya

8) Memiliki perhatian yang besar

Selanjutnya terdapat komponen kecerdasan interpersonal menurut Lwin dkk. (2008, hlm. 206-224) : 
1) Memahami perasaan orang lain

2) Berteman

3) Bekerja dengan teman-teman

4) Belajar mempercayai

5) Mengungkapkan kasih sayang

6) Belajar menyelesaikan masalah/ perselisihan kemasyarakatan (penyelesaian konflik)

\subsubsection{Faktor yang Mempengaruhi}

Faktor yang dapat mempengaruhi kecerdasan interpersonal anak adalah faktor internal dan faktor eksternal. Faktor internal merupakan faktor yang asalnya dari diri seseorang atau individu itu sendiri. Faktor ini biasanya berupa sikap atau sifat yang melekat pada diri seseorang misalnya anak mempunyai sifat pemalu. Sedangkan faktor eksternal merupakan faktor yang asalnya dari luar diri seseorang. Rustandi (2017, hlm.17) menyatakan ada beberapa faktor eksternal yang dapat mempengaruhi kecerdasan interpersonal anak, diantaranya: 1) Faktor keluarga; 2) Faktor teman sebaya; 3) Faktor Sekolah.

\subsubsection{Keterkaitan Permainan Treasure Hunt} dengan Kecerdasan Interpersonal

Permainan treasure hunt dirasa memiliki pengaruh untuk meningkatkan kecerdasan interpersonal pada anak. Hal ini ditandai dengan cara dalam bermain treasure hunt secara berkelompok, sehingga anggapan dasar peneliti permainan mempengaruhi kecerdasan interpersonal anak usia dini.

\section{METODE}

Arikunto (2013, hlm. 203) mengungkapkan bahwa "Metode penelitian adalah cara yang digunakan oleh peneliti untuk mengumpulkan data penelitiannya". Dengan demikian metode penelitian merupakan cara atau alat yang digunakan oleh peneliti untuk menjawab serangkaian pertanyaan yang dirumuskan dalam rumusan masalah.

\subsection{Desain Penelitian}

Dalam penelitian ini metode yang digunakan adalah studi literatur dengan mencari sumber referensi teori yang relevan dengan kasus atau permasalahan yang ditemukan. Dengan menggunakan jenis penelitian ini, peneliti akan menjadikan studi literatur sebagai pondasi atau alat utama untuk mendapatkan sumber data di lapangan yang berkaitan dengan "Permainan Treasure Hunt dan Kecerdasan Interpersonal Anak Usia 5-6 Tahun".

Kemudian Sukardi (2004, hlm. 34) menjelaskan mengenai macammacam dokumen atau sumber literatur diantaranya adalah, jurnal, laporan hasil penelitian, majalah ilmiah, surat kabar, buku yang relevan, hasil-hasil seminar, artikel ilmiah yang belum dipublikasi, narasumber, surat-surat keputusan dan sebagainya.

Dengan demikian, dalam peneliti menentukan topik yang akan dibahas yang kemudian dilanjutkan dengan mencari data-data baik itu yang relevan ataupun mendukung terhadap topik yang dibahas. Setelah mendapatkan data, penulis melakukan interpretasi atau penafsiran terhadap sumber data untuk memperoleh fakta tentang kajian yang akan dibahas. Setelah terkumpul maka data disusun secara sistematis dan terstruktur.

3.2 Jenis dan Sumber Data

Jenis dan sumber data yang digunakan oleh peneliti yaitu dengan menggunakan data dan sumber sekunder. Sugiyono (2011, hlm. 308) mengungkapkan bahwa "Sumber sekunder adalah sumber yang tidak langsung memberikan data kepada pengumpul, bisa lewat orang lain atau dokumen yang ditulis oleh orang lain". Dalam penelitian ini sumber sekunder merupakan beberapa penelitian yang sudah dilakukan atau tulisan tentang penelitian orang lain, tinjauan, ringkasan, kritikkan, dan beberapa tulisan mengenai hal yang tidak disaksikan atau tidak dilakukan oleh peneliti.penunjang yang berhubungan dengan persoalan yang dibahas. Data sekunder adalah jenis data yang dapat diperoleh dari jurnal, buku, dokumentasi maupun dari internet. 
3.3 Teknik Analisis Data

Sugiyono (2011, hlm. 308) menyatakan bahwa "Teknik pengumpulan dilakukan dalam berbagai setting, berbagai sumber, dan berbagai cara". Jenis data yang digunakan peneliti dalam penelitian ini adalah data primer, dengan melakukan observasi dan data sekunder yaitu data yang diperoleh peneliti dari jurnal, buku, dokumentasi maupun internet.

Teknik pengumpulan data yang dilakukan oleh peneliti yaitu dari beberapa buku dan jurnal relevan yang sesuai dengan topik permasalahan yang diangkat oleh peneliti.

\section{PEMBAHASAN}

Pembahasan ini mendeskripsikan hasil dari beberapa temuan yang telah dilakukan oleh peneliti terdahulu mengenai kemampuan kecerdasan interpersonal anak dan permainan treasure hunt sesuai dengan rumusan masalah.

4.1 Permasalahan dalam perkembangan kecerdasan interpersonal anak usia 5-6 tahun

Menurut Kamus Besar Bahasa Indonesia permasalahan merupakan hal yang menjadi masalah atau yang dimasalahkan. Sedangkan masalah merupakan sesuatu yang harus dipecahkan atau diselesaikan. Menurut Sugiyono (2009, hlm. 52) masalah merupakan penyimpangan antara yang seharusnya dengan apa yang benar-benar terjadi, antara teori dengan praktek, antara aturan dengan pelaksanaan, antara rencana dengan pelaksana. Dengan demikian permasalahan pada anak dapat diartikan sebagai gangguan yang muncul karena berbagai faktor. Masalah yang dihadapi oleh anak usia dini biasanya berkaitan dengan gangguan pada proses perkembangannya. Salah satu aspek yang penting untuk dikembangkan sebagai bekal dalam hidup di lingkungan sosial masyarakat adalah aspek sosial emosional. Setiap anak perlu memiliki keterampilan sosial dan kemampuan mengelola emosi yang baik untuk membangun hubungan di lingkungan sosial dengan beragam perbedaan. Keterampilan sosial mencakup kemampuan anak untuk mengenal diri sendiri, mengelola emosi, berempati, bersimpati, berbagi dan menolong sesama, bekerjasama, bersaing secara sehat, menjalin hubungan baik dengan orang lain atau biasanya berhubungan dengan kecerdasan interpersonal (Tadkiroatun Musfiroh, 2005, hlm. 68).

Untuk memahami bagaimana perkembangan kecerdasan interpersonal anak usia dini, perlu dipahami permasalahan-permasalahan apa saja yang dialami oleh anak selama masa perkembangannya. Hal ini dilakukan untuk mengetahui setiap perubahan yang terjadi pada diri anak. Permasalahan yang dihadapi anak dapat dilihat melalui tingkah laku atau perilaku yang ditunjukkan anak maupun keluhankeluhan yang disampaikan oleh orangorang sekitar anak. Misalnya ada anak yang sulit berbicara atau berkomunikasi dengan teman atau guru, sulit mengemukakan sesuatu, takut bertemu orang asing, pemilih dalam bergaul, tidak mampu bekerjasama dengan teman sebaya. Itu hanya sebagian contoh masalah kecerdasan interpersonal yang dihadapi anak.

Septiana dalam Candra W. Rahmawati (2015) menyatakan kurangnya seseorang memiliki keterampilan sosial menyebabkan timbulnya masalah dan kesulitan dalam berperilaku di sekolah, kenakalan, tidak perhatian, penolakan terhadap teman sebaya, kesulitan emosional, bullying (menggertak), kesulitan dalam berteman, agresif, bermasalah dalam hubungan interpersonal, miskin konsep diri, kegagalan akademik, kesulitan konsentrasi, isolasi dari teman sebaya, dan depresi. Selanjutnya menurut Saomah (2004, hlm. 2), permasalahan pada anak dalam sosial emosional yaitu 
perkembangan sosial anak berhubungan dengan kemampuan anak dalam berinteraksi dengan teman sebaya, orang dewasa atau lingkungan pergaulan yang lebih luas.

Diperjelas dengan hasil observasi awal/pra siklus yang dilakukan oleh Fitriah dan Julia (2018) selama bulan September 2017 di PAUD Bina Insani Kemala Bhayangkari 1 Banda Aceh terdapat permasalahan pada kemampuan interpersonal anak. Diantara permasalahan tersebut yaitu anak tidak mau bergabung bersama teman, anak bermain cuma dengan teman dekat saja, anak memilih-milih teman saat disuruh buat kelompok.

Permasalahan lain terdapat pada Jurnal Yenti (2018) berdasarkan observasi di lapangan pada RA Al-Istiqomah pada tanggal 1 januari 2018 bahwa kecerdasan interpersonal belum begitu muncul, hal ini dilihat pada saat anak-anak melakukan kerjasama dalam sebuah permainan pada saat istirahat. Kemudian rasa empati untuk membantu sesama teman dalam hal memberikan makanan ketika temannya tidak membawa bekal masih belum muncul. Permasalahan lainnya yaitu terletak pada sumber belajar, dimana anak hanya disuguhi dengan LKA (Lembar Kerja Anak), anak hanya dituntut untuk mengerjakan yang ada di LKA tersebut tanpa mempertimbangkan aspek lain dari anak didik tersebut.

Maka dari pemaparan di atas, dapat disimpulkan permasalahan kecerdasan interpersonal anak usia dini meliputi:

1) Kegiatan pembelajaran masih bersifat akademis

Kegiatan pembelajaran dianggap monoton dan sumber belajar hanya menggunakan LKA. Kurangnya perhatian khusus dari pendidik untuk menstimulus dan mengoptimalkan kecerdasan jamak, khususnya kecerdasan interpersonal anak dalam kegiatan pembelajaran. Dimana anak-anak masih belum mampu menerapkan kecerdasan interpersonal seperti takut dengan lingkungan baru, bermain secara individual, kurangnya interaksi komunikasi dengan teman sebaya, pemilih dalam bergaul atau bermain.

2) Belum dilaksanakan sebuah variasi khusus dalam kegiatan pembelajaran untuk meningkatkan kecerdasan interpersonal

Kurangnya sebuah variasi khusus oleh guru dalam pembelajaran untuk meningkatkan kecerdasan interpersonal, seperti masih belum dilakukan kegiatan berkelompok dimana hal itu dapat menstimulus anak dalam menjalin hubungan yang baik, berinteraksi dan bekerjasama dengan teman sebayanya.

3) Kurangnya media permainan untuk merangsang kecerdasan interpersonal

Media permainan masih dirasa kurang untuk meningkatkan kecerdasan interpersonal dalam bekerjasama, dimana kegiatan permainan hanya dilakukan secara individual saja.

4.2.2 Kemampuan kecerdasan interpersonal anak setelah menggunakan permainan treasure hunt

Peranan pendidik sebagai pengelola dalam kegiatan pembelajaran di lingkungan Pendidikan formal harus menyusun rencana kegiatan pembelajaran, persiapan pembelajaran, pelaksanakan kegiatan pembelajaran, serta mengevaluasi kegiatan pembelajaran. Tetapi tidak hanya hal tersebut saja yang perlu diperhatikan, melainkan kegiatan pembelajaran yang bermakna, menarik dan menyenangkan yang dapat menstimulus serta mengoptimalkan seluruh kecerdasan jamak, salah satunya kecerdasan interpersonal anak. Karena kecerdasan interpersonal anak sangat penting di stimulus sejak dini untuk membentuk pribadi anak yang lebih baik pada saat bersosialisasi dengan lingkungannya. Salah satu kegiatan pembelajaran yang dapat dilakukan yaitu melalui permainan treasure hunt atau permainan mencari harta karun. Karena pada dasarnya pembelajaran yang 
dilakukan pada anak yaitu bermain sambil belajar. Permainan treasure hunt ini suatu metode pembelajaran yang dilakukan secara berkelompok, sehingga dapat menstimulus kecerdasan interpersonal anak pada saat berinteraksi dalam permainan ini.

Sumantri M. S, Sugito (2015) dengan jurnalnya yang berjudul "Implementasi Metode Bermain Peran untuk Meningkatkan Kecerdasan Interpersonal Anak Usia 5-6 Tahun di TK Burunawati”. Dengan subjek penelitian yaitu anak didik kelas B usia 5-6 tahun di TK Barunawati Kota Ternate yang berjumlah 25 orang yang terdiri dari 10 anak laki-laki dan 15 anak perempuan. Hasil observasi persentase kecerdasan interpersonal anak sebelum dilakukan tindakan adalah sebesar 28\%, setelah dilakukan tindakan pada siklus I meningkat menjadi 44\%. Besar peningkatannya yaitu $16 \%$, kemudian setelah dilakukan tindakan pada siklus II, persentase kecerdasan interpersonalnya meningkat lagi menjadi $76 \%$. Besar peningkatannya yaitu $32 \%$. Berdasarkan hasil penelitian ini menunjukkan bahwa respons siswa terhadap pembelajaran melalui metode bermain mengalami peningkatan terhadap kecerdasan interpersonalnya yakni dari siklus I ke siklus II, adapun besar peningkatannya adalah $76 \%$.

Bellanca (2011 hlm. 196) menyatakan permainan "Treasure hunt merupakan suatu metode yang bertujuan untuk menemukan objek-objek yang mewakili konsep-konsep dalam pembelajaran. Kecerdasan yang terlibat dalam penerapan permainan treasure hunt adalah verbal (linguistik), visual (spasial), dan interpersonal". Jadi metode ini dapat digunakan untuk mengembangkan kecerdasan interpersonal anak.

Adapun temuan penelitian permainan treasure hunt yang dilakukan oleh Sitti Asma (2019) yang berjudul "Upaya Meningkatkan Kemampuan Kognitif Anak Usia Dini dalam Berhitung
Melalui Permainan Mencari Harta Karun di TK Pertiwi Kota Banda Aceh" Jenis Penelitian Penelitian ini merupakan penelitian tindakan kelas. terdapat pengaruh yang cukup baik dalam penggunaan media permainan treasure hunt terhadap kecerdasan interpersonal yaitu dapat dilihat pada saat kegiatan dilakukan secara berkelompok serta mampu bekerjasama dalam menyelesaikan permainan. Pada pelaksanaan siklus 1 melalui pertemuan ke-1 sampai dengan pertemuan ke-3 pelaksanaan pembelajaran dijumpai beberapa hambatan dan kelemahan, diantaranya persediaan media pada saat pelaksanaan permainan harta karun masih belum diterima oleh anak didik dalam mengembangkan kemampuannya, sehingga pada pertemuan ini permainan harta karun pada refleksi awal kemampuan masih belum berkembang secara baik. Selanjutnya pada siklus ke-2 melalui pertemuan ke-4 dan ke-5 dalam pelaksanaan pembelajaran melalui media permainan harta karun dijumpai peningkatan yang cukup signifikan walaupun masih ada beberapa hal yang masih kurang, yaitu pada pertemuan ke-4 a) Pengelolaan waktu yang efektif dalam melakukan permainan harta karun serta melakukan pembagian kelompok memudahkan peserta didik dalam mengikuti kegiatan b) Kemampuan bekerjasama peserta didik sudah mulai terlihat, akan tetapi ada anak yang belum mau bergantian menggunakan media dalam permainan harta karun. Kemudian pada pertemuan ke-5 Kemampuan bekerjasama peserta didik sudah mulai terlihat, akan tetapi ada anak yang belum mau bergantian menggunakan media dalam permainan harta karun.

Menurut Kim dan Yao (2010 hlm. 1858) dalam jurnalnya yang berjudul " $A$ Treasure Hunt Model for Inquiry-Based Learning in the Development of a Webbased Learning Support System" terdapat empat fase dalam menerapkan metode permainan treasure hunt, yaitu : 
1) Fase penyajian, guru memberikan informasi dan pertanyaan tentang topik yang akan dipelajari melalui permainan treasure hunt.

2) Fase mengingat, setelah siswa menerima informasi dan pertanyaan dari tahap sebelumnya, siswa mengingat dan menjelajah setiap tempat menggunakan clue (petunjuk) yang telah diberikan oleh guru.

3) Fase pengembangan, Siswa perlu memahami topik yang terkait serta bekerjasama dengan temannya sehingga dapat menjawab pertanyaan dengan benar melalui proses "membangun pengetahuan".

4) Fase evaluasi, pada fase ini siswa harus menjawab pertanyaan yang diterima pada fase pengembangan. Jawaban itu akan dievaluasi dan diakumulasikan perolehan nilai masing-masing kelompok. Pemenangnya adalah siswa atau tim dengan jumlah poin terbesar.

Peneliti merancang langkahlangkah pembelajaran menggunakan metode permainan treasure hunt berdasarkan tahapan tersebut, antara lain:

1) Guru menyiapkan clue atau petunjuk dan menyembunyikannya di dalam kelas.

2) Guru mengkondisikan siswa

3) Guru melakukan apersepsi pembelajaran menanyakan tentang tema misalnya binatang darat : "Apakah kalian tahu binatang yang hidup di darat?

4) Guru bertanya binatang apa saja yang ada di darat.

5) Guru menjelaskan sedikit materi tentang binatang di darat.

6) Guru membagi siswa menjadi tiga kelompok, masing-masing kelompok berjumlah 4 orang. Setelah dibagi kelompok, siswa berkumpul dengan kelompoknya.

7) Guru menjelaskan cara bermain menggunakan metode treasure hunt dan mendampingi masing-masing kelompok.

8) Setiap kelompok diberi nomor pengenal dan peta. Nomor ini berguna sebagai urutan siswa yang akan mencari clues atau petunjuk-petunjuk yang ada di dalam kelas.

9) Setelah itu siswa dipersilahkan untuk menjelajah setiap tempat sesuai dengan arahan peta dengan didampingi oleh guru.

10) Terdapat beberapa pos atau tempat persinggahan untuk menemukan sebuah clue atau petunjuk sebagai syarat untuk melanjutkan perjalanan ke pos selanjutnya sampai pos yang terakhir.

11) Setiap kelompok diberikan clue atau petunjuk dengan warna kertas yang berbeda agar mudah menemukannya.

12) Setiap kelompok mempunyai materi pembelajaran yang sama namun dengan urutan temuan yang berbeda.

13) Guru meminta siswa berdiskusi untuk menjawab pertanyaan yang diberikan. (Misalnya : binatang ini mempunyai kaki 4 , bulunya halus, telinganya runcing, dan suaranya miawww. Siapakah dia? Jawabannya : Kucing).

14) Guru menunggu jawaban siswa untuk mengkonfirmasi benar atau salah, jika belum benar maka siswa belum boleh mencari clue selanjutnya.

15) Guru meminta siswa mencari clue hingga siswa dengan nomor urut 4 dan menemukan harta karunnya. Harta karun itu sendiri berbentuk kotak yang didalamnya berisi kertas bergambar dan manik-manik, bulu yang akan mereka hias bersama-sama.

16) Pemenangnya adalah kelompok yang paling cepat menemukan harta karun dan menyelesaikan tantangan terakhir akan diberi hadiah.

17) Setelah menemukan harta karun, guru meminta siswa bekerja sama membuat karya dengan clue yang sudah didapat tadi menjadi bentuk gambar binatang yang utuh.

18) Guru meminta setiap kelompok menceritakan mengenai binatang tersebut.

Selanjutnya Rofiah (2017, hlm. 23) mengemukakan metode permainan treasure hunt ini memiliki manfaat sebagai berikut : 
1) Menumbuhkan sikap kerjasama, karena setiap siswa berkontribusi dalam melakukan permainan.

2) Menimbulkan antusias untuk memecahkan setiap clue, karena setelah memecahkan clue kelompok akan mendapat harta karun

3) Menumbuhkan semangat siswa dalam memecahkan setiap clue.

Maka analisis penulis melalui beberapa pemaparan penelitian di atas, proses pembelajaran yang dilakukan dengan mengimplementasikan metode permainan treasure hunt dapat berpengaruh terhadap peningkatan kecerdasan interpersonal anak usia 5-6 tahun. Hal ini karena metode ini menekankan hubungan interaksi antar individu baik itu dengan teman, guru, orang tua dan lingkungan masyarakat sekitar. Pada saat bermain, terjadi interaksi sosial antar individu yang secara sengaja dengan diwadahi permainan treasure hunt. Metode permainan treasure hunt merupakan variasi dalam kegiatan pembelajaran yang dapat meningkatkan dan melatih kecerdasan interpersonal anak untuk mampu bekerja sama, berkomunikasi, dapat bergaul dengan orang lain, dapat memahami suasana hati orang lain seperti marah, senang dan sedih serta dapat memberikan dorongan positif pada orang lain. Permainan treasure hunt juga sebagai media untuk merangsang dan mempengaruhi perkembangan kecerdasan interpersonal anak usia dini dengan sangat baik. Melalui permainan treasure hunt, secara tidak sadar akan terjadi interaksi antar anggota kelompok dan akan timbul rasa saling percaya serta menumbuhkan sikap kerjasama karena setiap siswa berkontribusi dalam melakukan permainan treasure hunt untuk mengungkap dan menyelesaikan masalah secara bersama-sama. Dari hasil pembahasan dalam permainan treasure hunt itu maka anggota kelompok (siswa) dapat belajar dari pengalaman baru yang berupa penilaian ingatan dan pemahaman yang alami. Saat kegiatan permainan treasure hunt ini dilaksanakan, menimbulkan antusias dan semangat siswa untuk memecahkan setiap clue (petunjuk) karena akan terjadi hubungan komunikasi antara pemimpin kelompok dan antara anggota kelompok sehingga akan tercipta suatu pemahaman melalui diskusi dan tanya jawab antara anggota kelompok mengenai topik yang sedang dibahas dan mampu menyelesaikan permainan dengan menemukan harta karun yang sesungguhnya.

\section{KESIMPULAN}

Berdasarkan hasil data dari beberapa temuan yang telah dilakukan oleh peneliti terdahulu, maka dapat disimpulkan bahwa dengan menerapkan permainan treasure hunt dapat berpengaruh terhadap kecerdasan interpersonal anak usia 5-6 tahun.

Proses pembelajaran yang dilakukan dengan menerapkan metode permainan treasure hunt dapat menjadi alternatif dalam kegiatan pembelajaran untuk merangsang dan meningkatkan kecerdasan interpersonal anak. Hal ini karena permainan treasure hunt menekankan kerjasama antar anggota kelompok dan hubungan interaksi baik itu dengan teman ataupun guru. Melalui permainan treasure hunt, secara tidak sadar akan terjadi interaksi antar anggota kelompok dan akan timbul rasa saling percaya serta menumbuhkan sikap kerjasama karena setiap siswa berkontribusi dalam melakukan permainan treasure hunt untuk mengungkap dan menyelesaikan masalah secara bersama-sama. Dari hasil pembahasan dalam permainan treasure hunt maka anggota kelompok (siswa) dapat belajar dari pengalaman baru yang berupa penilaian ingatan dan pemahaman secara alami.

\section{SARAN}

Pada penelitian selanjutnya peneliti menyarankan beberapa hal: Pertama untuk melatih kemampuan 
kecerdasan interpersonal anak melalui permainan treasure hunt sebaiknya dilakukan di luar kelas agar lebih maksimal. Kedua, untuk menggunakan metode permainan treasure hunt ini disesuaikan dengan tema dan sub tema. Ketiga, pada metode permainan treasure hunt ini perlu ketelitian serta persiapan yang matang untuk menentukan dan meletakkan clue (petunjuk) dan informasi agar tidak terjadi kekeliruan pada saat mengambil clue (petunjuk) tersebut.

\section{DAFTAR PUSTAKA}

Arikunto, S. (2013). Prosedur Penelitian Suatu Pendekatan Praktik. Jakarta: Rineka Cipta.

Asma, Sitti. (2019). Upaya Meningkatkan Kemampuan Kognitif Anak Usia Dini dalam Berhitung Melalui Permainan Mencari Harta Karun di TK Pertiwi Kota Banda Aceh. Jurnal: Serambi PTK , Volume VI, No.2, hlm. 45-54.

Gardner, H. (2003). Multiple Intelligence (Kecerdasan Majemuk) Teori dan Praktek. Jakarta: Interaksara.

Hayati, F. \& Julia. (2018). Peningkatan Kemampuan Interpersonal Melalui Permainan Balon Berpasangan di Kelompok Bermain PAUD Bina Insani Kemala Bhayangkari 1 Banda Aceh. Jurnal: Buah Hati, Vol. 5, No. 1, hlm. 63-71.

Ismail, A. (2006). Education Games (Menjadi Cerdas dan Ceria dengan Permainan Edukatif). Yogyakarta: Pilar Media.

Juniarti, Yenti. (2018). Peningkatan Kecerdasan Interpersonal Anak Usia Dini Melalui Media Celemek Pintar. Jurnal: AUDI, vol 3, No. 1.

Kim, D.W. \& J. T Yao. (2010). A Treasure Hunt Model for Inquiry-Based Learning in the Development of a Web-based Learning Support System. Journal: University Computer Sciense, Vol. 16, No 14, hlm. 1853-1881.

Kohen-Vacs, D., M. Ronen., \& S. Cohen. (2012). Mobile Treasure Hunt Games for Outdor Learning. Journal: Bulletin of the IEEE Technical Committee on
Learning Technology, Vol. 14, No. 4, hlm. 24-26.

Lwin, May., Adam K., Kenneth L. \& Caroline S. (2008). How to multiply your child's intelligence (Cara Mengembangkan Berbagai Komponen Kecerdasan). Jakarta: PT.Indeks

Peraturan Menteri Pendidikan dan Kebudayaan Republik Indonesia No. 146 Tahun 2014 Tentang Kurikulum 2013 Pendidikan Anak Usia Dini.

Peraturan Menteri Pendidikan dan Kebudayaan Republik Indonesia No. 137 Tahun 2014 Tentang Standar Nasional Pendidikan Anak Usia Dini.

Rahmawati, C. K. (2015). Identifikasi Kecerdasan Interpersonal Anak Usia 45 Tahun di Tk Gugus Sido Mukti Mantrijeron Yogyakart. Jurnal: Pendidikan Anak Usia Dini Edisi 6 Tahun ke-4 201.

Rofiah, Nuzulul. (2017). Upaya Meningkatkan Kerjasama dan Prestasi Belajar Siswa Mata Pelajaran IPS Materi Perkembangan Teknologi Produksi, Komunikasi dan Transportasi Melalui Metode PermainanTreasure Hunt. (Tesis). Universitas Muhammadiyah Purwokerto.

Rustandi, D.F. (2017). Kemampuan Interpersonal Anak Usia Dini. (Skripsi). Sekolah Strata-1, Universitas Pendidikan Indonesia Kampus Tasikmalaya, Kota Tasikmalaya.

Safaria, T. (2005). Interpersonal Intelligence. Yogyakarta : Amara Books.

Saomah, Aas. (2004). Makalah PermasalahanPermasalahan Anak dan Upaya Penanganannya. Cimahi

Sugiyono. (2015). Metode Penelitian Kuantitatif, Kulitatif, dan $R \& D$. Bandung : Alfabeta.

Sugiyono. 2009. Metode Penelitian Pendidikan (Pendekatan Kuantitatif, Kualitatif, dan $R$ \& D). Bandung: IKAPI.

Sujiono, Y.N. (2009). Konsep Dasar Pendidikan Anak Usia Dini. Jakarta: Permata Puri Media. 
Sukardi. (2014). Metodologi penelitian pendidikan kompetensi dan praktiknya. Jakarta: Bumi Aksara.

Sumantri M.S. \& Sugito, (2015). Implementasi Metode Bermain Peran untuk Meningkatkan Kecerdasan Interpersonal Anak Usia 5-6 Tahun di TK Barunawati. Jurnal: Pendidikan dan Pemberdayaan Masyarakat, Vol. 2, No. 1, hlm. 85-93.

Suparno, P. (2013). Teori Intelligensi Ganda dan Aplikasinya di Sekolah. Yogyakarta: Kanisius.

Tadkiroatun, Musfiroh, 2005. Bermain Sambil Belajar dan Mengasah Kecerdasan. Jakarta: Depdiknas

Undang-Undang Sistem Pendidikan Nasional No. 20 Tahun 2003

Yaumi, M. (2012). Pembelajaran Berbasis Multiple Intelligences. Jakarta: Dian Rakyat. 